\title{
Prevalence of High Arsenic Concentration in Darbhanga District of Bihar: Health Assessment
}

\author{
Abhinav A ${ }^{1}$, Sneha Navin ${ }^{1}$, Arun Kumar ${ }^{2 *}$, Ranjit Kumar ${ }^{2}$, Mohammad Ali ${ }^{2}$, Shishir Kumar Verma ${ }^{1}$ and Ashok Kumar Ghosh ${ }^{2}$ \\ ${ }^{1}$ LN Mithila University, Darbhanga, Bihar, India \\ ${ }^{2}$ Mahavir Cancer Sansthan and Research Centre, Patna, Bihar, India
}

\begin{abstract}
Background: Arsenic (As) in the groundwater is widely recognised as a global threat to human health. Millions of people from different countries including India are heavily dependent on groundwater containing elevated levels of arsenic for both drinking and irrigation purposes. Bihar and West Bengal located within the Middle-Gangetic plain (MGP), are the two worst arsenic exposed states in India. Today it is estimated that more than 5 million people in the Bihar state are drinking water with arsenic concentration greater than permissible limit of $10 \mu \mathrm{g} / \mathrm{L}$ recommended by World Health Organisation. In the present study, four villages Paghari, Habidih situated under Baheri block and Parri, Bairampur situated under Biraul block of Darbhanga districts of Bihar was taken up for the groundwater arsenic and blood arsenic estimation. The arsenic causing health related problems were also evaluated in the rural population.

Methods: Altogether 48 groundwater samples from Hand Tube Wells (HTWs) of four different villages (12 groundwater samples from each village) were randomly collected for arsenic estimation and 48 blood samples were collected from the subject of the same household for blood arsenic estimation (12 blood samples from each village). Assessment of health related problems due to arsenic poisoning was also carried out in this study.

Results: The highest arsenic concentration in groundwater was found to be $911 \mu \mathrm{g} / \mathrm{L}$ in Paghari village of Baheri block while in blood sample it was $252 \mu \mathrm{g} / \mathrm{L}$ observed from the same household in the Paghari village. The typical arsenicosis symptoms like hyperkeratosis in the palm and sole, melanosis of the skin and few cases of cancer were also reported among the population.

Conclusions: The present study thus, concludes that there was high arsenic concentration in the groundwater of four villages of Darbhanga district. Presence of arsenic in the blood samples indicates as a biomarker of arsenic exposure. Arsenic poisoning has caused severe health related problems in these population. Therefore, a proper strategy is urgently required to mitigate the groundwater arsenic contamination and minimize the severity of the arsenic poisoning in these villages.
\end{abstract}

Keywords: Arsenic poisoning; Groundwater; Blood; Darbhanga district; Health assessment

\section{Introduction}

Safe drinking water is a fundamental human right and it is the basic need of individuals. Over the past three decades, occurrence of high concentration of arsenic in the groundwater has been recognised as a major public health concern in several parts of the world including India [1]. Seventy countries have been recently identified as arsenic affected areas and it is likely that many other areas with elevated arsenic in groundwater will be found in the future [2].

Arsenic is abundant in the crust of the earth and is found in all environments. It is found in soil, minerals and groundwater in various forms [3]. Arsenic in the groundwater exists primarily as oxy anions representing two oxidation states: arsenite (As III) and arsenate (As V) [4]. Both exist within the $\mathrm{pH}$ range of 6-9. It is well-established fact that arsenite (As III) is more toxic than arsenate(As V) $[5,6]$. World Health Organization (WHO) estimates that more than 200 million persons worldwide might be chronically exposed to arsenic in drinking water at concentrations above the WHO safety standard of $10 \mu \mathrm{g} / \mathrm{L}[7]$.

The entire Gangetic plain of India-the upper Ganga plains, the middle Ganga plains and the lower Ganga plains are the areas with very high population density, the land here is highly fertile and agriculture is the main occupation and source of income of the rural population. Groundwater is the main source of drinking, cooking, agriculture and other household purposes. Bihar and West Bengal are located within the Middle-Ganga Plains (MGP) and are the two worst arsenic contaminated states in India [8,9]. Presently, about 18 districts of Bihar are affected due to arsenic contaminated groundwater [10]. It is estimated that more than 5 million people in the Bihar state are drinking water with arsenic concentration greater than the permissible limit i.e., $10 \mu \mathrm{g} / \mathrm{L}$ [11]. Majority of the affected population belong to rural areas and economically very poor. Population of these areas are still drinking arsenic contaminated groundwater and are not aware of this fact and its consequences. Furthermore, as majority of the arsenic exposed population are poverty stricken, malnutrition is serious issue which aggravates impact of arsenic on their health. The continuous consumption of elevated arsenic through drinking water (more than five years) may lead to arsenic poisoning commonly known arsenicosis as melanosis, leuco-melanosis, keratosis, skin lesions in sole and palm and skin cancer [8-10]. In addition to skin lesions and skin cancer; neurological, respiratory, cardiovascular, developmental effects and more are linked to chronic arsenic exposure [11-13].

${ }^{*}$ Corresponding author: Arun Kumar, Mahavir Cancer Sansthan and Research Centre, Phulwarisharif, Patna, Bihar-801 505, India, Tel: +9334740800; E-mail: arunk31@rediffmail.com

Received October 12, 2016; Accepted October 20, 2016; Published October 24 2016

Citation: Abhinav A, Navin S, Kumar A, Kumar R, Ali M, et al. (2016) Prevalence of High Arsenic Concentration in Darbhanga District of Bihar: Health Assessment. J Environ Anal Toxicol 6: 410. doi: 10.4172/2161-0525.1000410

Copyright: ( 2016 Abhinav A, et al. This is an open-access article distributed unde the terms of the Creative Commons Attribution License, which permits unrestricted use, distribution, and reproduction in any medium, provided the original author and source are credited. 
Citation: Abhinav A, Navin S, Kumar A, Kumar R, Ali M, et al. (2016) Prevalence of High Arsenic Concentration in Darbhanga District of Bihar: Health Assessment. J Environ Anal Toxicol 6: 410. doi: 10.4172/2161-0525.1000410

Page 2 of 7

The Darbhanga district of Bihar is situated between latitude $\mathrm{N} 25^{\circ} 53^{\prime} 26.27^{\prime \prime}$, longitude $\mathrm{E} 85^{\circ} 45^{\prime} 25^{\prime \prime}$. Its average distance is $80 \mathrm{~km}$ away from the northern bank of river Ganges and its geographical area is $2,279 \mathrm{sq}$. $\mathrm{km}$. The total population of the district is $39,21,971$ (Census 2011) [14]. First incidence of arsenic contaminated groundwater was reported from Biraul block of Darbhanga districts in 2005 [15]. The incidence of groundwater arsenic contamination was increased at a high rate in several districts of Bihar in last decades and previous studies suggest that arsenic contamination is most prevalent in rural areas [8].

Therefore, present study was undertaken in four villages under two blocks of Darbhanga district to know the prevalence of arsenic concentration in groundwater as well in the biological samples. This novel study will be first ever study carried out in this area.

\section{Materials and Methods}

\section{Ethical approval}

The research work was approved by the IEC (Institutional Ethics Committee, MCS Patna) of the institute as the work was on human subjects. The survey work was carried out in the months from January to May 2015.

\section{Location}

The present study was carried out in four villages under two blocks Baheri and Biraul of Darbhanga district. The Paghari village $\left(25^{\circ} 59.311^{\prime} \mathrm{N}, 086^{\circ} 00.207^{\prime} \mathrm{E}\right)$ and the Habidih village $\left(26^{\circ} 00.585^{\prime} \mathrm{N}\right.$, $\left.086^{\circ} 05.739^{\prime} \mathrm{E}\right)$ comes under Baheri block while, the Parri village $\left(25^{\circ} 58.832^{\prime} \mathrm{N}, 086^{\circ} 08.574^{\prime} \mathrm{E}\right)$ and the Bairumpur village $\left(25^{\circ} 54.743^{\prime} \mathrm{N}\right.$, $\left.086^{\circ} 07.681^{\prime} \mathrm{E}\right)$ comes under Biraul block. The average population and the number of households (population/households) in all the four villages Paghari, Habidih, Parri and Bairumpur were respectively 4416/900, 32612/5000, 6908/1400 and 2855/500 [14].

\section{Arsenic analysis and survey}

Collection of samples: The water sample bottles $(250 \mathrm{ml}$ polypropylene bottle) were well cleaned and pre-treated with $1 \%$ hydrochloric acid. Altogether, 48 groundwater samples (12 groundwater samples from each village) were randomly collected in duplicates from hand tube wells (HTWs) of the households situated at every 50 meter of distance in the villages. Each HTW was flushed for ten minutes to get the actual representative groundwater samples following Nickson's protocol [16]. For determining the exact location of the HTWs, hand held Global Positioning System (GPS) receivers (Garmin etrex10, USA) with an accuracy of $\approx 10 \mathrm{~m}$ was utilized. The depth of the hand tube wells were also recorded (as told by the house-owners during sample collection) for the correlation of arsenic concentration in groundwater with the depth of HTWs. Blood samples were collected from people living in these villages with their consent and as per ethical norms. Twelve blood samples from each village of same households (where groundwater samples were analysed) for a total 48 blood samples $(2 \mathrm{ml}$ each) were collected in a vacutainer to estimate blood arsenic concentration. After the collection, groundwater samples were analysed instantly by utilizing Merckoquant Arsenic Field Test Kit (Merck, Germany) to know the trace of arsenic in the water samples. For the final confirmation and quantification of total arsenic present in groundwater as well as in blood samples, the samples were analysed as per the NIOSH protocol through Graphite Furnace Atomic Absorption Spectrophotometer (Pinnacle 900T, Perkin Elmer, Singapore) [17] at Mahavir Cancer Research Institute and Research Centre, Patna.
Health assessment: The suspected people of the villages were exclusively interrogated and examined for arsenic related diseases to know their health status. For this a questionnaire method was utilized and health related data were extensively collected [11].

\section{Statistical analysis}

Data were analysed with statistical software (Graphad Prism 5) and values were expressed as mean \pm SEM. Differences between the group were analysed by one way analysis of variance (ANOVA) using the Dunnet's test while scattered graphs were plotted through another statistical software SPSS-16.0 using linear regression analysis methods [8].

\section{Results}

\section{Groundwater arsenic assessment}

Groundwater analysis of all the 48 samples collected from the four villages represented high prevalence of arsenic contamination. The highest arsenic concentration recorded in the groundwater sample was $911 \mu \mathrm{g} / \mathrm{L}$ from Paghari village. Overall maximum arsenic concentration recorded in the groundwater samples of all the four villages were 911 $\mu \mathrm{g} / \mathrm{L}$ in Paghri, $201 \mu \mathrm{g} / \mathrm{L}$ in Habidih, $843 \mu \mathrm{g} / \mathrm{L}$ in Parri, $862 \mu \mathrm{g} / \mathrm{L}$ in Bairampur respectively (Figure 1).

\section{Blood arsenic assessment}

Altogether, 48 blood samples (12 blood samples from each village) were analysed for total arsenic concentration. The highest arsenic concentration in the blood sample of the subject was $252 \mu \mathrm{g} / \mathrm{L}$ of Paghri village. Overall $45 \%$ of the blood samples showed arsenic concentrations above the permissible limit i.e., $1 \mu \mathrm{g} / \mathrm{L}$ in blood as recommended by WHO and EPA (Figure 2).

\section{Health assessment}

Altogether 500 subjects (125 subjects from each village) were interviewed during heath assessment. Many villagers exhibited typical symptoms of arsenicosis like hyperkeratosis in sole and palm melanosis, and leuco-melanosis. Blackening of teeth and nails were also observed in many persons of the arsenic exposed population. Few of them exhibited hyperpigmentation (spotted pigmentation) on their whole body (Figure 3). Apart from typical symptoms of arsenicosis, other health related problems like gastrointestinal, liver, neurological disorder and hormonal imbalance were frequently observed. Incidence of cancer especially skin, liver and breast were frequently observed in Paghari village. The interviewed persons reported that many people died of cancer in last two decades.

\section{Correlation coefficient study}

Correlation coefficient between groundwater arsenic concentration and depth of HTWs: Average depth of the HTWs of all the four villages included in this study was between 100-150 feet. Arsenic concentration observed in groundwater was much higher in shallow HTWs in comparison to deep HTWs which showed a positive correlation (Figure 4).

Correlation coefficient between blood arsenic level and groundwater arsenic level: The study showed significant increase in blood arsenic levels with increased groundwater arsenic levels. Although, few blood samples did not correlate with elevated groundwater arsenic levels (Figure 5). 

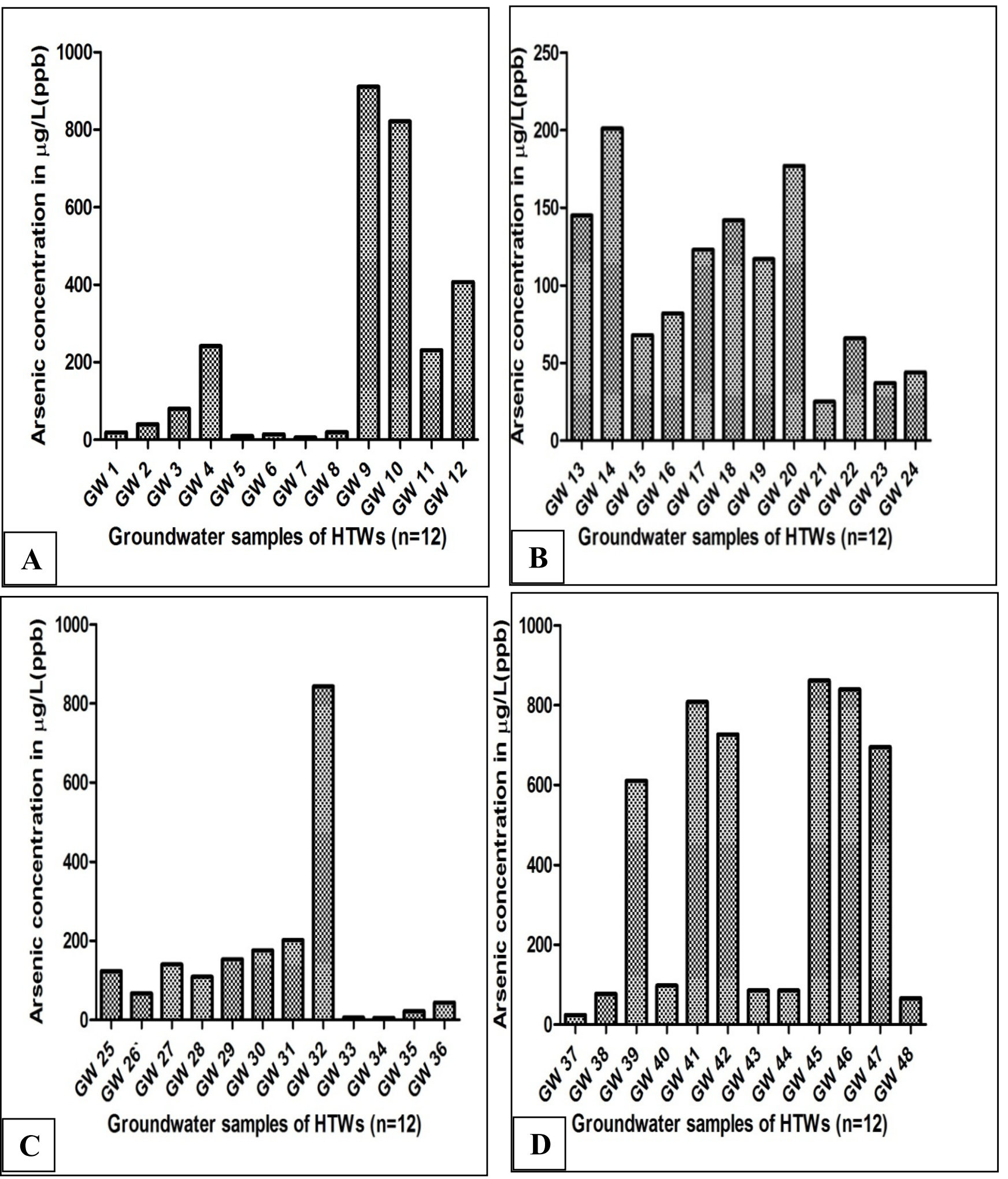

Figure 1: Arsenic level in the Groundwater of all the four villages (A) Paghari (B) Habidih (C) Parri and (D) Bairampur. 

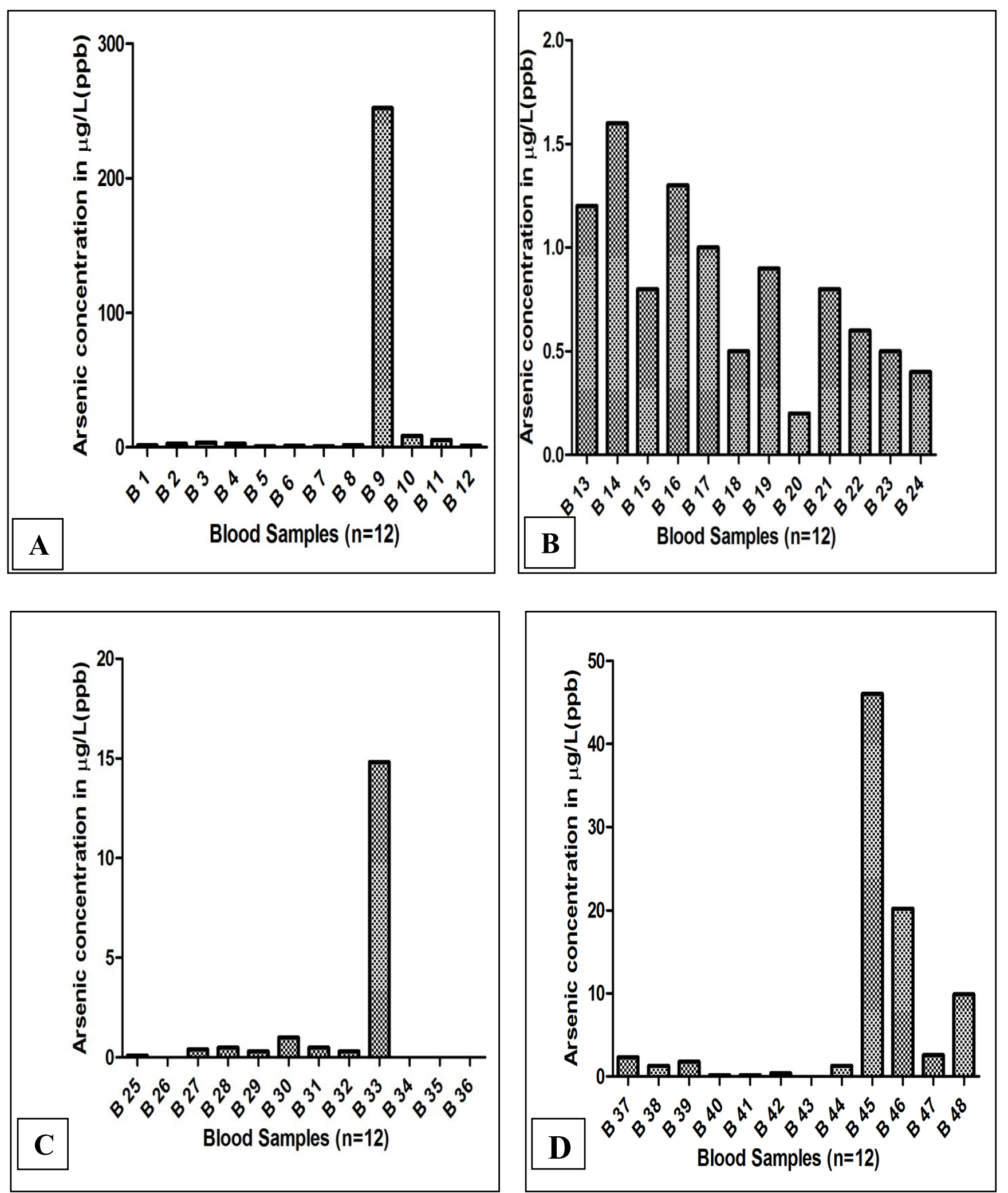

Figure 2: Arsenic level in the blood samples of the village people of all the four villages (A) Paghari (B) Habidih (C) Parri and (D) Bairampur. 
Citation: Abhinav A, Navin S, Kumar A, Kumar R, Ali M, et al. (2016) Prevalence of High Arsenic Concentration in Darbhanga District of Bihar: Health Assessment. J Environ Anal Toxicol 6: 410. doi: 10.4172/2161-0525.1000410

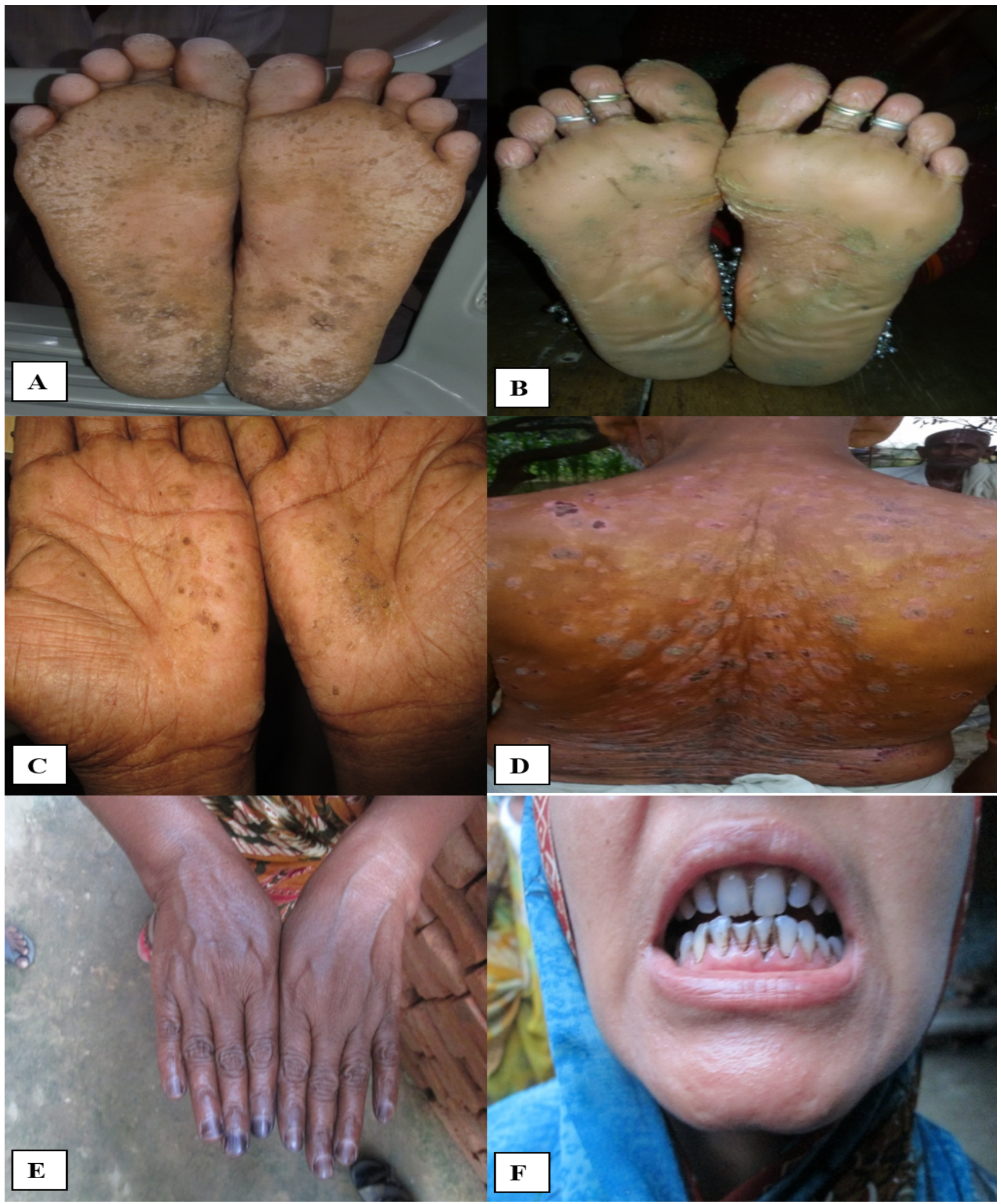

Figure 3: (A) Hyperkeratosis of sole in 60 year old male. (B) Hyperkeratosis of sole in 40 year old female. (C) Hyperkeratosis of palm in 40 year old male. (D) Hyperpigmentation of whole body in 85 year old male. (E) Blackening of nails in 32 year old female. (F) Tooth decay in 25 old Female. 
Citation: Abhinav A, Navin S, Kumar A, Kumar R, Ali M, et al. (2016) Prevalence of High Arsenic Concentration in Darbhanga District of Bihar: Health Assessment. J Environ Anal Toxicol 6: 410. doi: 10.4172/2161-0525.1000410

Page 6 of 7

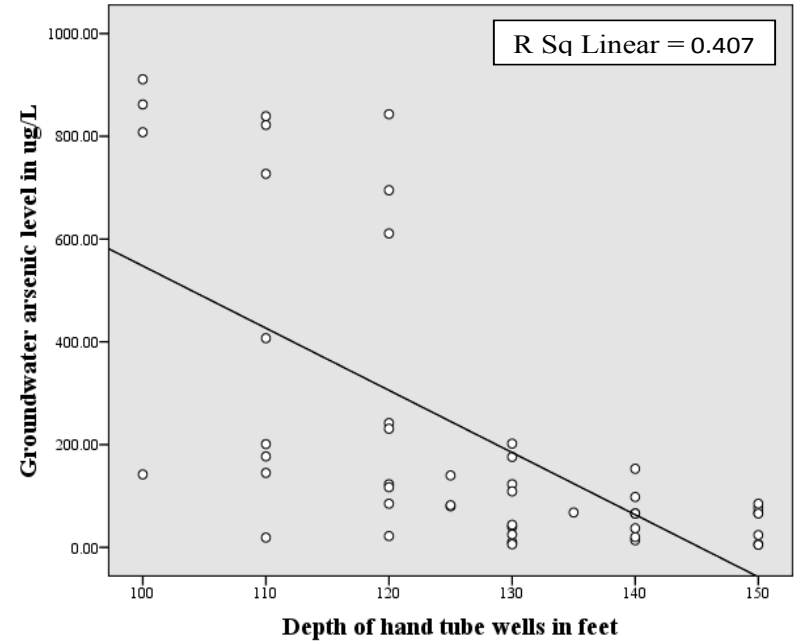

Figure 4: Correlation coefficient between groundwater arsenic level and depth of HTW HTWs.

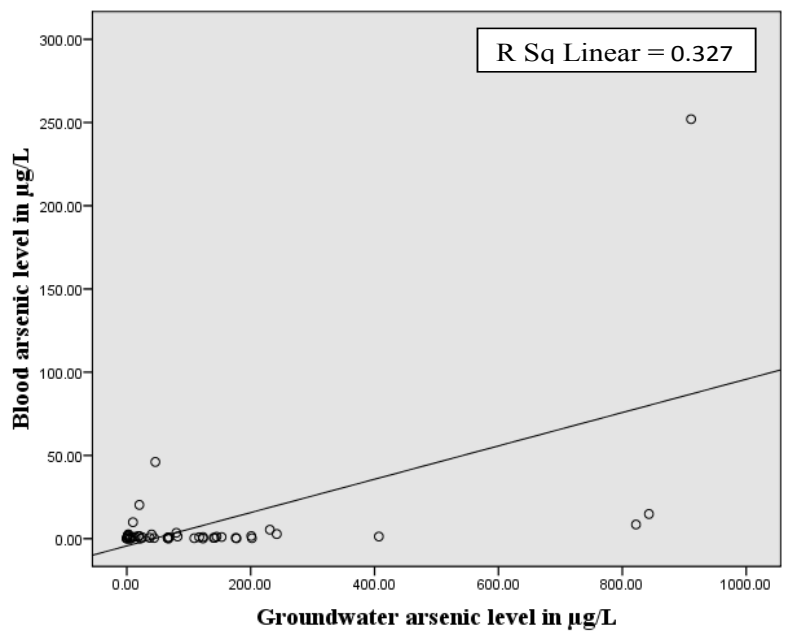

Figure 5: Correlation coefficient between blood arsenic level and groundwater arsenic level.

\section{Discussion}

Groundwater arsenic contamination in the Lower Gangetic Plain of West Bengal, India, was first identified in July 1983 along with patients with arsenical skin lesions belonging to the same villages in these districts $[18,19]$. After two decades of this incidence first foot print of groundwater arsenic poisoning in the Middle Gangetic Plain of Bihar, India, was identified in July 2002, in Semaria Ojhapatti village of Shahpur block of the Bhojpur district $[9,20]$. Incidence of groundwater contamination and its adverse effect on health in the population of state Bihar increased at a higher rate. Presently 18 districts of Bihar state are under threat of arsenic poisoning and majority of districts belongs to the nearer areas of bank of the river Ganges [10,21].

First incidence of arsenic contaminated groundwater was jointly reported by two government agencies in only one block of Darbhanga district in $2005[22,23]$. The concentration of arsenic in the groundwater at that time was not much higher as compared to the other districts of Bihar residing near the bank of the river Ganga. After a decade, in the present study four villages of Darbhanga district showed very high contamination of arsenic poisoning in the Groundwater of their hand pumps. $911 \mu \mathrm{g} / \mathrm{L}$ is the maximum observed value of total arsenic reported from Paghari village of Baheri block which is much higher than the permissible limit. Detection of elevated arsenic in the groundwater from villages of Darbhanga district which is located about $80 \mathrm{~km}$ north of the river Ganga, indicates that contamination may be spread even to areas far off from the river Ganga. Geographical parameters like shifting of water table downwards, leaching of toxic chemicals in the groundwater and over exploitation of groundwater are the suggested regions of arsenic elevation in the groundwater far from river Ganga [7,24].

World Health Organisation (WHO) and the U.S. Environmental Protection Agency (EPA) have well recommended threshold of $10 \mu \mathrm{g} / \mathrm{L}$ for inorganic arsenic concentration in drinking water while $1 \mu \mathrm{g} / \mathrm{L}$ for human blood $[7,24]$. The elevated level of arsenic in the groundwater as well in blood samples of four villages are at very alarming condition. Village population are directly exposed with the elevated levels of arsenic via drinking water and indirectly via cooking food in arsenic contaminated water. People belonging to these villages are adversely affected with arsenic poisoning. The arsenicosis symptoms observed in the subjects of the studied villages were the first ever study done in the Darbhanga district. Although various studies carried out in India have been well documented $[8,9,25]$. Apart from typical symptoms of arsenicosis other health related problems and few cases of skin, liver and bladder cancer are also observed in the population of study area. Arsenic has also been classified as Class I carcinogen by the International Agency of research on Cancer (IARC) which means that there is a sufficient evidence of its carcinogenicity to human. Skin and several types of internal cancer including bladder, kidney, liver and prostate have been found associated with arsenic ingestion [26-30].

The study on blood arsenic level in the population of Darbhanga district of Bihar has been assayed for the first time. The blood arsenic level with the subject age and the duration of exposure through drinking water is the novel work ever done in this area. Various studies on estimation arsenic in the hair, nail, urine and blood samples and its correlation with groundwater arsenic concentration have been well documented in other parts of the country $[8,9,31]$. The measurement of high arsenic in the groundwater and its correlation with blood arsenic level is the unique and first ever study done in these villages. Thus, the study concluded that, arsenic poisoning in the four villages of Darbhanga district of Bihar has causes severe health hazards. Therefore, an immediate strategy is required to cater the severity of the arsenic poisoning.

\section{Disclosure of Interest}

The authors declare that they have no conflict of interest concerning this article.

\section{Acknowledgement}

The authors extended their appreciation to the INSPIRE-Fellowship Division, Department of Science and Technology, Ministry of Science and Technology, Govt. of India, New Delhi for the financial assistances of this work and Mahavir Cancer Institute \& Research Centre, Patna for the entire infrastructure facility.

\section{References}

1. Chaurasia N, Mishra A, Pandey SK (2012) Finger Print of Arsenic Contaminated Water in India - A Review. J Forensic Res 3: 172.

2. Bundschuh J, Litter MI, Bhattacharya $P(2010)$ Targeting arsenic-safe aquifers for drinking water supplies. Environ Geochem Health 32: 307-315. 
Citation: Abhinav A, Navin S, Kumar A, Kumar R, Ali M, et al. (2016) Prevalence of High Arsenic Concentration in Darbhanga District of Bihar: Health Assessment. J Environ Anal Toxicol 6: 410. doi: 10.4172/2161-0525.1000410

Page 7 of 7

3. Antman KH (2001) Introduction: the history of arsenic trioxide in cancer therapy. Oncologist 6 Suppl 2: 1-2.

4. Navin S, Das AJ, Verma C, Kumar M, Kumar R (2013) Arsenic in the environment effectuates human health: An imperative need to focus. Int. Res. J. Environment Sci 2: 101-105.

5. Shankar S, Shanker U, Shikha (2014) Arsenic contamination of groundwater: a review of sources, prevalence, health risks, and strategies for mitigation. Scientific World Journal 2014: 304524

6. Azcue JM, Nriagu JO (1994) Arsenic in environment: cycling and characterisation. J Wiley and Sons Inc., pp: 1-15.

7. World Health Organization (1993) Guideline for drinking water quality. 3rd edn. Geneva, Switzerland, p: 515.

8. Kumar A, Ali Md, Rahman S Md, Iqubal A Md, Anand G, et al. (2015) Ground Water Arsenic Poisoning in "Tilak Rai Ka Hatta" Village of Buxar District, Bihar, India Causing Severe Health Hazards and Hormonal Imbalance. J Environ Anal Toxicol 5: 290 .

9. Chakraborti D, Mukherjee SC, Pati S, Sengupta MK, Rahman MM, et al. (2003) Arsenic groundwater contamination in Middle Ganga Plain, Bihar, India: a future danger? Environ Health Perspect 111: 1194-1201.

10. Singh SK (2015) Groundwater arsenic contamination in the middle-gangetic plain, Bihar (India): A danger arrived. Int Res J Environment Sci 4: 70-76.

11. Singh SK, Ghosh AK, Kumar A, Kislay K, Kumar C, et al. (2014) Groundwater arsenic contamination and associated health risks in Bihar, India. International Journal of Environmental Research 8: 49-60.

12. Naujokas MF, Anderson B, Ahsan H, Aposhian HV, Grasiano JH, et al. (2013) Broad scope of health effect from chronic arsenic exposure: Update on a worldwide public health problem. Environment Health Perspectives 121: 295302

13. Flora SJ (2011) Arsenic-induced oxidative stress and its reversibility. Free Radic Biol Med 51: 257-281.

14. Census (2011) Interim Report of Population Census of India.

15. Saha D (2009) Arsenic groundwater contamination in parts of middle Ganga plains, Bihar. Current Sciences 97: 753-755.

16. Nickson R, Sengupta C, Mitra P, Dave SN, Banerjee AK, et al. (2007) Current knowledge on the distributaion of arsenic in groundwater in five states in India. Journal of Environmental Sciences and Health Part A, Toxic/Hazardous substances and Environmental Engineering 42: 1707-1718.

17. National Institute of Occupational Safety and Health (1994) Element in blood or tissue. Method: 8005 . In: NIOHS manual of analytical method. 4th edn.
Cincinnati, OH. Department of Health and Human services. DHHS Publication pp: 94-113.

18. Saha KC (1984) Melanokeratosis from arsenic contaminated tubewell water Indian J Dermatol 29: 37-46.

19. Garai R, Chakraborty AK, Dey SB, Saha KC (1984) Chronic arsenic poisoning from tube-well water. J Indian Med Assoc 82: 34-35.

20. Singh SK, Ghosh AK (2012) Health risk assessment due to groundwater arsenic contamination: children are at high risk. Human and Ecological Risk Assessment: An International Journal 18: 751-766.

21. Singh SK, Vedwan N (2015) Mapping composite vulnerability to groundwater arsenic contamination: An analytical framework and a case study in India. Naturals Hazards 75: 1883-1908.

22. Report (2005) Central Ground Water Board. Government of India and Public Health Engineering Department, Government of Bihar, Patna, p: 35.

23. Joint Report (2007) Central Groundwater Board. Goverment of India and Groundwater Investigation Directorate, Government of Bihar, Patna, India.

24. USEPA (1999) Guideline for Carcinogen Risk Assessment. Risk Assessment Forum, NCEA-F-0644. US Environmental Protection Agencies: Washington DC, USA.

25. ATSDR (2005) US Agency for Toxic Substance and Disease Registry Toxicological profile for arsenic.

26. International Agency for Cancer Research (IARC) (2004) Some drinking water disinfectant and contaminants including arsenic: IARC Monograph on the Evaluation of Carcinogenicity Risks to humans. WHO 84.

27. Smith AH, Goycolea M, Haque R, Biggs ML (1998) Marked increase in bladder and lung cancer mortality in a region of Northern Chile due to arsenic in drinking water. Am J Epidemiol 147: 660-669.

28. Morales KH, Ryan L, Kuo TL, Wu MM, Chen CJ (2000) Risk of internal cancers from arsenic in drinking water. Environ Health Perspect 108: 655-661.

29. Ferreccio C, González C, Milosavjlevic V, Marshall G, Sancha AM, et al (2000) Lung cancer and arsenic concentrations in drinking water in Chile. Epidemiology 11: 673-679.

30. Andrew AS, Karagas MR, Hamilton JW (2003) Decreased DNA repair gene expression among individuals exposed to arseic in United States drinking water. Int J Cancer 104: 263-268.

31. Iyer S, Sengupta C, Velumani A (2016) Blood arsenic: Pan-India prevalence. Clin Chim Acta 455: 99-101. 